\title{
Familial forms of nephrotic syndrome
}

\author{
Gianluca Caridi • Antonella Trivelli • \\ Simone Sanna-Cherchi • Francesco Perfumo • \\ Gian Marco Ghiggeri
}

Received: 4 June 2008 /Revised: 8 October 2008 / Accepted: 8 October 2008 /Published online: 9 December 2008

(C) IPNA 2008

\begin{abstract}
The recent discovery of genes involved in familial forms of nephrotic syndrome represents a breakthrough in nephrology. To date, 15 genes have been characterized and several new loci have been identified, with a potential for discovery of new genes. Overall, these genes account for a large fraction of familial forms of nephrotic syndrome, but they can also be recognized in 10 $20 \%$ of sporadic cases. These advances increase diagnostic and therapeutic potentials, but also add higher complexity to the scenario, requiring clear definitions of clinical, histopathological and molecular signatures. In general, genetic forms of nephrotic syndrome are resistant to common therapeutic approaches (that include steroids and calcineurin inhibitors) but, in a few cases, drug response or spontaneous remission suggest a complex pathogenesis. Finally, syndromic variants can be recognized on the basis of the associated extra-renal manifestations. In this educational review, clinical, histological and molecular aspects of various forms of familial nephrotic syndrome have been reviewed in an attempt to define a rational diagnostic approach. The proposed model focuses on practical and
\end{abstract}

G. Caridi · G. M. Ghiggeri

Laboratory on Physiopathology of Uremia,

G. Gaslini Children Hospital,

Genoa, Italy

S. Sanna-Cherchi

Department of Medicine, Division of Nephrology,

Columbia University College of Physicians and Surgeons,

New York, NY, USA

A. Trivelli $\cdot$ F. Perfumo - G. M. Ghiggeri $(\bowtie)$

Division of Nephrology, Dialysis and Transplantation,

G. Gaslini Children Hospital,

Largo G. Gaslini, 5,

16148 Genova, Italy

e-mail: labnefro@ospedale-gaslini.ge.it economic issues, taking into consideration the impossibility of using genetic testing as starting diagnostic tool. The final objective of this review is to outline a diagnostic flow-chart for clinicians and geneticists and to generate a rational scheme for molecular testing.

Keywords Molecular genetics $\cdot$ Nephrin .

Nephrotic syndrome $\cdot$ Podocin $\cdot$ Podocytes

\section{Introduction}

With an estimated [1] annual incidence of between 2.0 and 2.7 cases per 100,000 children in the USA and a cumulative prevalence of 16 per 100,000 [2,3], idiopathic nephrotic syndrome (NS) is the prevailing glomerular disease in children. It is defined as the association of gross proteinuria with hypoalbuminemia, edema and hyperlipidemia, a condition that usually requires prolonged and combined treatments, and one that may recur over years. Nephrotic syndrom appears to be a clinically heterogeneous disease characterized by different histological variants [4-6] and genetic determinants [7-9]. The recent discovery of genes involved in idiopathic NS represents a milestone in nephrology. Most of these genes code for structural elements of the slit diaphragm and of podocyte cytoskeleton (NPHS1, NPHS2, CD2AP, TRCP6, ACTN4); others are expressed in the glomerular basement membrane $(L A M B 2)$ and in mitochondria (COQ2) (see Table 1). Yet another group includes transcription factors necessary for normal podocyte function and development (WT1, $L M X 1 B)$. A thorough definition of histopathological features is crucial for a correct genetic approach to idiopathic NS since, in many cases, a genotype-phenotype correlation can help to address the underlying molecular defect. 
Table 1 Principle genes involved in familial nephrotic syndrome and in associated syndromes

\begin{tabular}{|c|c|c|c|c|c|c|}
\hline Syndromes & Gene & Locus & Protein & Inheritance & $\begin{array}{l}\text { Prevalent } \\
\text { histology }\end{array}$ & $\begin{array}{l}\text { OMIM } \\
\text { number }\end{array}$ \\
\hline \multicolumn{7}{|l|}{ Familial nephrotic syndrome } \\
\hline $\begin{array}{l}\text { Nephrotic syndrome, } \\
\text { Finnish type }\end{array}$ & NPHS1 & $19 \mathrm{q} 13.1$ & Nephrin & $\mathrm{AR}$ & $\begin{array}{l}\text { DMS, } \\
\text { microcysts }\end{array}$ & 602716 \\
\hline $\begin{array}{l}\text { Nephrotic syndrome, } \\
\text { steroid-resistant type } 2\end{array}$ & NPHS2 & $1 \mathrm{q} 25-31$ & Podocin & $\mathrm{AR}$ & FSGS & 604766 \\
\hline $\begin{array}{l}\text { Nephrotic syndrome, } \\
\text { steroid-resistant type } 3\end{array}$ & PLCE1 & $10 \mathrm{q} 23$ & Phospholipase C epsilon 1 & $\mathrm{AR}$ & DMS & 610725 \\
\hline Denys-Drash syndrome & $W T 1$ & $11 \mathrm{p} 13$ & Wilms tumor 1 gene & $\mathrm{AD}$ & DMS & 194080 \\
\hline Frasier syndrome & $W T 1$ & $11 \mathrm{p} 13$ & Wilms tumor 1 gene & $\mathrm{AD}$ & FSGS & 136680 \\
\hline $\begin{array}{l}\text { Focal segmental } \\
\text { glomerulosclerosis type } 1\end{array}$ & ACTN4 & $19 \mathrm{q} 13$ & Alpha-Actinin 4 & $\mathrm{AD}$ & FSGS & 603278 \\
\hline $\begin{array}{l}\text { Focal segmental } \\
\text { glomerulosclerosis type } 2\end{array}$ & TRPC6 & $11 \mathrm{q} 21-22$ & $\begin{array}{l}\text { Transient receptor potential } \\
\text { cation channel, homolog of } 6\end{array}$ & $\mathrm{AD}$ & FSGS & 603965 \\
\hline $\begin{array}{l}\text { Focal segmental } \\
\text { glomerulosclerosis type } 3\end{array}$ & $C D 2 A P$ & $6 \mathrm{p} 12$ & CD2-associated protein & $\mathrm{AR} / \mathrm{AD}$ & FSGS & 607832 \\
\hline \multicolumn{7}{|l|}{ Associated syndromes } \\
\hline $\begin{array}{l}\text { Schimke immuno-osseous } \\
\text { dysplasia }\end{array}$ & SMARCAL1 & $2 q 34-q 36$ & $\begin{array}{l}\text { SWI/SNF-related, matrix-associated, } \\
\text { actin-dependent regulator of } \\
\text { chromatin, subfamily a-like protein } 1\end{array}$ & $\mathrm{AR}$ & FSGS & 242900 \\
\hline Pierson syndrome & $L A M B 2$ & $3 \mathrm{p} 21$ & Laminin beta 2 & $\mathrm{AR}$ & FSGS & 609049 \\
\hline COQ2 deficiency & $C O Q 2$ & $4 q 21-q 22$ & Parahydroxybenzoate-polyprenyltransferase & $\mathrm{AR}$ & $\begin{array}{l}\text { FSGS, } \\
\text { Collapsing }\end{array}$ & 607426 \\
\hline Leigh syndrome & PDSS2 & $6 \mathrm{q} 21$ & Decaprenyl diphosphate synthase, subunit 2 & $\mathrm{AR}$ & $\begin{array}{l}\text { FSGS, } \\
\text { Collapsing }\end{array}$ & 607426 \\
\hline $\begin{array}{l}\text { AMRF syndrome (Action } \\
\text { myoclonus-renal failure } \\
\text { syndrome) }\end{array}$ & $S C A R B 2 / L I M P 2$ & $4 q 13-q 21$ & Scavenger receptor class $\mathrm{B}$, member 2 & $\mathrm{AR}$ & FSGS & 254900 \\
\hline
\end{tabular}

$A R$ Autosomal recessive; $A D$ autosomal dominant; DMS diffuse mesangial sclerosis; FSGS focal segmental glomerulosclerosis; OMIM Online Mendelian Inheritance in Man database; SWI/SNF swItch/sucrose nonfermentable nucleosome remodeling complex

Nevertheless, there is wide overlap between different forms and cases of uncommon associations, such as the presence of diffuse mesangial sclerosis in patients with NPHS2 mutations or focal glomerulosclerosis in patients with variants in the PLCE1 gene.

Even though the review of the histopathological aspects of idiopathic NS is not within the scope of our educational review and readers should refer to specialized papers [10-12], a few remarks could facilitate comprehension. A distinction is generally accepted between a first group that includes minimal change disease (MCD), mesangial proliferation with deposition of IgM (MesIgM) and focal segmental glomerulosclerosis (FSGS) as different stages of the same entity and a second one only represented by diffuse mesangial sclerosis (DMS) [13]. It is important to stress that FSGS is not a single condition but includes five histological variants, i.e. collapsing FSGS, tip lesion, cellular variant, perihilar lesions and a final one without specified alterations. Recognizing these sub-categories has diagnostic, therapeutic and prognostic implications. Collapsing FSGS is, for example, usually associated with human immunodeficiency virus (HIV) infection and with mitochondrial defects, while the unspecified variant is often associated with NPHS2 mutations. In the diagnostic flowchart used at Istituto Giannina Gaslini (Fig. 1), the definition of renal histopathology plays a central role for addressing the molecular approach. This scheme is applied to all children presenting with NS in the first year of life and in children between two and 14 years of age with steroid resistance.

\section{Genetic variant associated with FSGS/MesIgM/MCD}

There are several genes causing isolated FSGS/MesIgM/MCD with both autosomal recessive (AR) (NPHS2) and dominant (AR) (ACTN4, TRPC6) inheritance and other modes (such as in the case of $C D 2 A P$ ), which are currently under investigation. Overall, recessive forms are more frequent than dominant traits, and NPHS2 is by far the gene most frequently implicated in FSGS.

NPHS2/podocin (AR) (OMIM\#604766) The NPHS2 gene codes for podocin, which is a raft-associated component of 
Idiopathic Nephrotic Syndrome

$<1$ yrs and up to 14 yrs

in case of steroid resistance

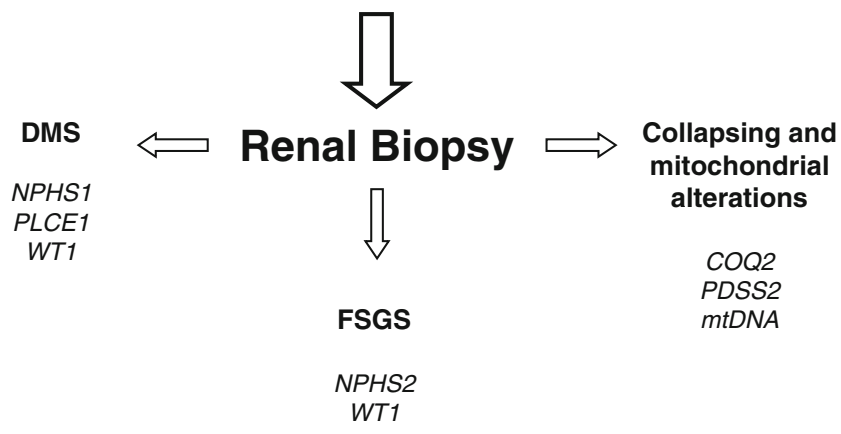

Fig. 1 Diagnostic flow-chart in children with early onset nephrotic syndrome $(<1$ year) or in patients $<14$ years demonstrating steroid resistance. Steroid resistance was defined by lack of anti-proteinuric effect after 45 days with prednisone $2 \mathrm{mg} / \mathrm{kg}$ and three pulses with methyl-prednisolone $10 \mathrm{mg} / \mathrm{kg}$. DMS Diffuse mesangial sclerosis, FSGS focal segmental glomerulosclerosis, NPHS1 nephrin gene, NPHS2 podocin gene, PLCE1 phospholipase C epsilon 1 gene, WT1 Wilm's tumor 1 gene, $C O Q 2$ para-hydroxybenzoate-polyprenyltransferase gene, PDSS2 decaprenyl diphosphate syntase gene, $m t D N A$ mitochondrial DNA

the glomerular foot-process membrane where the protein is localized at the insertion of the slit-diaphragm [8, 14, 15] (GenBank NM_014625; NP_055440). Podocin belongs to the stomatin domain family proteins, which are uniquely expressed in the kidney glomeruli where they interact with nephrin and CD2AP. Mutations in the NPHS2 gene have been initially identified in families with AR-FSGS, where they account for most familial nephrotic syndromes with recessive inheritance [8]. Extensive data have also been published on NPHS2 mutational screenings in patients with sporadic NS with recessive inheritance [16-21], most of whom are children with steroid resistance. Overall, NPHS2 mutations have been reported to account for a significant proportion of all nephrotic patients, corresponding roughly to $45-55 \%$ of familial forms and $8-20 \%$ of sporadic disease, with variations according to the different patient cohorts and the different sub-phenotypes studied. However, the actual incidence is probably much higher if only patients with a poor response to steroids and/or showing a pathological picture of FSGS are considered. More than 40 NPHS2 mutations have been reported to date that involve the whole length of the gene; these determine every kind of alteration, including deletions, splice site, missense and nonsense variants. The onset of proteinuria has been reported to occur at different ages, but generally before the $14^{\text {th }}$ year of life. A few cases of congenital NS have been described, including two families with double homozygous p.R168H and p.P20L mutations [16, 19]. With respect to a possible genotype-phenotype correlation, some inferences can be drawn: (1) p.R138Q appears to be associated with early onset NS (at $12 \pm 3$ months of age in 15 patients) whereas p.V180M and p.R238S are associated with a late onset form (at $129 \pm 12$ months in seven patients); (2) carriers of the association of p.R229Q variant with other NPHS2 mutations present late onset proteinuria, generally between the first and second decades of life; (3) carriers of NPHS2 mutations generally do not respond to drugs commonly used in NS, with the exception of four partial responders to cyclosporin described by Ruf and colleagues [18]; (4) progression to end stage renal failure is rapid in all cases and usually occurs within the first decade of life [21]. Data on histopathological phenotype are available for 48 patients with homozygous or compound heterozygous NPHS2 mutations and for 15 with p.R229Q associated with another NPHS2 mutation. Focal segmental glomerulosclerosis was the prevailing glomerular lesion in 39 patients of the former group and in 15 of the p.R229Q/ heterozygous NPHS2 cohort. Ten patients had milder renal changes epitomized by mesangial proliferation with $\operatorname{IgM}$ deposition in eight cases and minimal changes nephropathy in two. Finally, a few cases presented DMS and one biopsy showed a nonspecific $\mathrm{C} 3$ deposition $[17,18]$. Therefore, the variability of renal histopathological phenotype associated with NPHS2 mutations limits in some way the possibility of a simple diagnosis based on two diagnostic tests (histology and NPHS2 sequence). A major confounder is represented by the presence, even if unusual, of DMS, which can complicate the molecular approach.

TRPC6/transient receptor potential cation channel, homolog of 6 (AD) (OMIM\#603965) The TRCP6 gene codes for a glomerular slit diaphragm-associated channel that is required for normal renal function. It is implicated in several biological functions, but mainly in intracellular ion homeostasis and calcium entry into cells. TRCP6 was first localized to chromosome 11q21-22 by Winn and colleagues [22] and then identified as a cause of FSGS in a large pedigree study from New Zealand [23]. Subsequently, Reiser and colleagues [24] confirmed TRPC6 mutations in another five unrelated families of different ancestry in which mutations were inherited following an AR mode with reduced penetrance. Five of the described mutations predicted an amino acid change-one in the ankyrin domain, two in the N-terminal intracellular domain and two in the C-terminal intracellular domain - and only one generated a stop codon at the $\mathrm{C}$ terminus. Functional studies of three families showed that TRPC6 mutations increased the influx of calcium into cells. One likely explanation is that increased intracellular calcium modifies the contractile structure of podocytes or, alternatively, high calcium may cause podocytopenia through apoptosis, detachment or lack of proliferation. Clinical features related to TRCP6 mutations are rather homogeneous since the first 
symptoms occur in the third-fourth decade of life and usually consist of severe proteinuria that is always associated with FSGS. Progression to end stage renal failure has been reported in $50 \%$ of the patients [25].

ACTN4/Alpha-Actinin-4 (AD) (OMIM\#603278) Mutations of $A C T N 4$, the gene coding for $\alpha$-Actinin 4 , cause a rare form of familial autosomal-dominant NS with reduced penetrance. The function of this protein is to crosslink actin filaments and connect them to the glomerular basement membrane. To date, six families and sporadic cases have been reported [9, 26, 27], all showing a mild increase in urine protein excretion during adolescence or early adulthood and slow progression to end stage renal failure in some affected individuals. In all cases described to date, the ACTN4 mutations were in close proximity (exon 8) and predicted an amino acid change in the actin-binding domain. This finding suggests the existence of a mutational hot-spot that would facilitate, if confirmed in a larger population, the molecular work-up. Classical FSGS is the most frequent histopathologic lesion related to ACTN4 mutations, but one child showing the collapsing variant associated with rapidly progressing NS in early childhood has also been reported [27].

\section{CD2AP/CD2-associated protein (AR/AD) (OMIM\#607832)}

$\mathrm{CD} 2$-associated protein $(C D 2 A P)$ is an adapter molecule originally identified as a ligand for the $\mathrm{T}$ cell-adhesion protein CD2. It is an $80-\mathrm{kDa}$ cytoplasmic protein expressed in all tissues except the brain. In the kidney, CD2AP is localized to podocytes. The results of experiments in mice with targeted disruption of CD2AP [28] and functional studies [29] strongly suggest that $C D 2 A P$ is a putative gene in inherited NS. A unique patient with a homozygous truncating mutation of $C D 2 A P$ (stop codon at amino acid position 612) has been recently described by Löwik and colleagues [30]. This patient had developed early onset NS with a histological pattern sharing some features of FSGS and diffuse mesangial sclerosis patterns. A few other patients with NS and heterozygous mutations of $C D 2 A P$ have also been reported. In a first report based on the results of their study on 45 African-Americans, Kim et al. [31] described a heterozygous nucleotide variant resulting in aberrant $C D 2 A P$ splicing in two patients with idiopathic FSGS and HIV infection. Three heterozygous mutations (c. $944 \mathrm{~A}>\mathrm{T}$; c.1161A $>\mathrm{G}$; c.1573delAGA) producing amino acid changes (p.K301M, p.T374A) or a deletion in functional domains (p.delG525), respectively, were found in three unrelated patients in Italy [32], and the functional consequences of these were studied in two. One mutation (p.K301M) resulted in defective CD2-CD2AP interaction and clustering; the other (c.1573delAGA) was associated with the down-regulation of $C D 2 A P$ and podocin glomer- ular expression. All three patients presented overt proteinuria with steroid NS at variable ages (one in adulthood; the other two in childhood), and FSGS was the corresponding histopathological finding. Haplo-insufficiency of CD2AP due to heterozygous mutations may confer susceptibility to glomerular disease and integrity, as suggested by experiments in $C D 2 A P$ heterozygous knockout mice [31].

\section{Genetic variants associated with isolated DMS}

Diffuse mesangial sclerosis is a common histopathological feature in renal biopsies of patients with congenital NS. It is characterized by mesangial expansion and sclerosis that evolve towards obliteration of the capillary lumen and contraction of the glomerular tuft. Typically, there is no cell proliferation in DMS; rather, there is an accumulation of collagen-like fibrils in the mesangium and glomerular basement membrane, causing thickening. The immunofluorescence is usually negative. Diffuse mesangial sclerosis does not represent a single entity, but is associated with several syndromic disorders, such as Denys-Drash, Galloway-Mowat, Pierson, carbohydrate-deficient glycoprotein syndrome type I (see below) and even with viral infections. In some cases, such as in NS of the Finnish type, DMS is associated with diffuse microcysts and has been described separately from the pure glomerular form.

PLCE1/phospholipase C epsilon (AR) (OMIM \#610725) Phospholipase $C$ epsilon is a cytoplasmatic enzyme that is required during podocyte maturation. PLCE1 gene mutations have been recently identified in association with congenital NS in several families from Turkey and one from Israel, and PCLE1 is currently considered to be a major gene responsible for NS during the first year of life [33]. Children lacking PCLE1 for truncating mutations present DMS that is due to a complete block of glomerular maturation at the 23rd gestational week. More recently, PCLE1 truncating mutations were identified in ten of 35 children with isolated DMS (28.3\%), suggesting that PLCE1 mutations are a major cause of DMS [34]. A less severe course characterized by FSGS and slower progression to end stage renal failure has been reported in patients with PLCE1 missense mutations, implying a genotypephenotype correlation and suggesting the clinical relevance of genetic testing [35]. It has also been proposed that renal histopathological patterns reflect the different kidney developmental stages at which PCLE1 activity is required. According to this hypothesis, DMS results from a developmental arrest due to truncating PLCE1 mutations, whereas FSGS is the phenotype arising from low-level or dysfunctional PLCE1 in the case of less severe molecular 
defects [35]. A further unexpected finding was a complete response to steroid treatment in a girl with a homozygous truncating PLCE1 mutation [35]. It seems reasonable to propose that, in this case, steroids could have activated some cellular response downstream of PLCE1 that substitutes phospholipase in the immunosuppressive effect.

\section{Congenital nephrosis of the Finnish type}

NPHS1/nephrin (AR) (OMIM\#256300) Nephrin is probably the most structurally important protein in podocytes where it represents the major constituent of the slitdiaphragm at the regulation site for ultra-filtration of proteins. It is encoded by NPHSl, a $26-\mathrm{kb}$ gene located on chromosome 19q13.1 [36]. Mutations in NPHS1 cause an AR disorder characterized by a congenital NS that is common in Finland; for this reason it is called Finnish nephropathy (FN). Finnish nephropathy is also present outside Finland and, in a recent survey of 80 sporadic cases [37], NPHS1 mutations accounted for $22.5 \%$ of nephrotic cases in the first year of life and was second to only NPHS2 as a causal factor of NS. More than 90 NPHS1 mutations have been identified so far [38, 39]. In Finland, most patients have mutations in exons 2 and 26, defined as $\mathrm{Fin}_{\text {major }}\left(80 \%\right.$ of cases) and $\mathrm{Fin}_{\text {minor }}$, respectively. These mutations cause truncated proteins of 90 and 1109 amino acids, respectively, leading to the absence of nephrin in the slit-diaphragm. A variety of mutations (missense, nonsense, splice, deletions and insertions) have been reported outside Finland in association with variable phenotypes [7, 40]. Missense mutations, that are frequently observed outside Finland cause a milder phenotype (see below). Molecular studies demonstrated an altered subcellular distribution of these mutant nephrins, which accumulate in endoplasmic reticulum and do not reach the cell membrane [41, 42].

Renal histopathology in FN biopsies at 3 months of life showed mixed glomerular and tubulointerstitial lesions. Glomerular lesions vary from mesangial hypercellularity to glomerular sclerosis and/or diffuse mesangial sclerosis. Tubular aspects are more characteristic and include diffuse cystic dilatations of proximal and distal tubules (also known as microcysts); interstitial fibrosis and inflammation are usually present and increase with age. Immunofluorescence is always negative and electron microscopy shows foot process effacement and villous transformation [43, 44]. Nephrin staining provides a definitive diagnosis in those cases with truncating mutations since the slit diaphragm, that is mainly composed of nephrin, may be absent in nonsclerotic glomeruli. This is particularly important for a differential diagnosis between FN and other congenital nephrotic syndromes since nephrin staining can help to detect the underlying defect [45].
The disease is characterized by severe proteinuria often present 'in utero' and almost always appearing in the first year of life. Steroid and calcineurin inhibitor resistance and the requirement for albumin infusion and parenteral nutrition characterize this life-threatening condition. Disease course is rapidly progressive, and end stage renal failure generally occurs within the first decade of life. In rare cases, FN may have a mild phenotype. Patrakka and colleagues [46] described a patient with compound heterozygous Fin $_{\text {minor }}$ and missense mutations who responded to indomethacin and angiotensinconverting enzyme (ACE) inhibitors, and another four cases with missense mutations associated with remittent proteinuria have been reported in Japan [47] and in Germany [39].

A recent report by Philippe and colleagues [42] emphasizes the occurrence of mild clinical phenotypes. They described a good clinical outcome in six patients who actually carried at least one severe mutation that in most cases determined a truncating protein. Histology showed MCD in five patients and FSGS in one patient; clinical follow-up was characterized by a good anti-proteinuric effect of corticosteroids alone or in association with cyclosporin. One child had normal renal function at 6 years of age despite the absence of therapy.

The co-existence of NPHS1 and NPHS2 mutations was observed in a few patients in association with congenital FSGS or FN [48]. This result underlines a functional link between nephrin and podocin that is also supported by cellular studies on their interaction [49]. The results of molecular studies suggested that, in order to produce congenital NS, a triple hit is required, with a homozygous event in one gene and the third mutation acting as modifier of the others. The renal phenotype in carriers of this defect ranges from FN to congenital FSGS, thereby supporting the theory that these disorders can be regarded as part of a spectrum, with the resulting effect being determined by the molecular background. These observations also highlight that, in the presence of FSGS and/or DMS, the molecular diagnosis should incorporate the analysis of both NPHS2 and NPHS1 according to a flow chart that starts with NPHS1 in the case of FN, and NPHS2 in the case of FSGS.

\section{Syndromic forms}

Denys-Drash (OMIM\#194080) and Frasier syndromes (OMIM\#136680) Denys-Drash (DDS) and Frasier syndromes (FS) are caused by WT1 gene mutations. This gene codes for a transcriptional factor (Wilms' tumor suppressor protein) of the zinc-finger protein family that is involved in kidney and gonadal development. It consists of ten exons and is localized on chromosome 11q13. It leads to four different isoforms, depending on alternative splicing [50]. After birth, WT1 protein expression is restricted to renal podocytes 
where it probably contributes to maintaining cellular differentiation [51]. Germline heterozygous WT1 mutations have been extensively reported in the literature as the cause of the two predominant sporadic phenotypes, i.e. DDS and FS, which are characterized by different combinations of NS with genital anomalies and pseudo-hermaphroditism [52, 53]. $W T 1$ is also known as the cause of sporadic and familial Wilms tumor [50], which is the most common solid tumor in childhood and represents a potential evolution of DDS. Genetic variations and clinical phenotypes allow an easy differentiation between DDS and FS since over 95\% of DDS carry missense mutations in exons 8 and 9 , while FS is more frequently associated with specific splice site mutations at IVS9, resulting in the presence or absence of a tri-peptide of lysine-threonine serine (KTS) in exon 9. In terms of renal involvement, DDS is predominantly characterized by diffuse mesangial sclerosis with early onset and rapid evolution to end stage renal failure, while FS usually presents slowly progressive FSGS, although rare variants with glomerular basement membrane involvement have been reported [54]. The real impact of WT1 mutations in children with steroid resistant nephrotic syndrome (SRNS) has been recently evaluated by Ruf and colleagues [55] and in an extended cohort by Mucha and colleagues [56]. These studies showed an overall incidence of 7\%, with a prevalence of FS over DDS phenotypes. It was striking that only one female out of eight with FS presented XY inversion and sexual anomalies that have long been considered a key sign of the syndrome. This finding strongly supports the need for the mutational analysis of WT1 in children affected by NS with steroid resistance in order to avoid potentially harmful therapeutic interventions. An extension of screening studies to large cohorts of children and adults with SRNS is the natural consequence of the above findings. Aucella and colleagues [57] screened 115 patients with SRNS and 86 with steroid dependence ( 85 adults) for $W T 1$ mutations, with results that partially confirm the findings of Ruf and colleagues [55]. This study [57] also extends the basic histopathologic picture of FS to unusual renal findings, describing two cases with thinning of the basement membrane and with the presence of foam cells in the interstitium that appear to represent the prevalent early feature in FS patients.

Pierson syndrome (OMIM\#609049) Pierson syndrome [58] is caused by mutations in the $L A M B 2$ gene that codes for laminin $\beta 2$, a protein widely expressed in the glomerular basement membrane, retina, lens capsule and neuromuscular synapses [59]. The syndrome, characterized by microcoria and abnormal lens shape and cataract, is associated with NS that develops 'in utero' or within the first 3 months of life. The renal histopathologic lesion is DMS, and the outcome is usually a rapid progression to renal failure. In addition, patients surviving infancy develop blindness and severe neurological deficits [60]. The classical form is caused by truncating mutations of $L A M B 2$ [61]. Missense and non-truncating mutations of $\angle A M B 2$ are associated with a milder phenotype without microcoria or with minor structural eye anomalies, always with histological evidence of FSGS [62, 63]. Finally, LAMB2 missense and truncating mutations have been reported in two cases presenting congenital NS without any ocular anomalies [64], suggesting that $L A M B 2$ may be implicated in inherited NS more frequently than expected.

Schimke immuno-osseous dysplasia (OMIM\#242900) Schimke immuno-osseous dysplasia is an AR condition characterized by spondyloepiphyseal dysplasia with T-cell immunodeficiency and glomerulosclerosis [65]. Hypothyroidism and episodes of cerebral ischemia were found to be associated in a fraction of patients [66]. In 2002, Boerkoel and colleagues identified mutations of the SMARCAL1 gene in 26 families with the disease, most of whom presented a severe phenotype [67]. SMARCAL1 codes for a protein that participates in DNA remodeling after replication. Schimke immuno-osseous dysplasia is a clinically heterogeneous disease since severity ranges from a very early onset and death in the first years of life to milder forms that start in the first decade of life and survive beyond the second. In this disease, glomerulosclerosis evolves to end-stage renal failure requiring replacement treatment and renal transplantation.

Action myoclonus-renal failure syndrome (OMIM\#254900) Action myoclonus-renal failure syndrome (AMRF) is an AR condition characterized by progressive myoclonus epilepsy associated with renal failure. Proteinuria is the hallmark and first symptom of the disease. Age at onset is between 15 and 20 years, and glomerulosclerosis with focal collapse is the usual histopathologic picture. Neurological symptoms, i.e. tremor, action myoclonus, seizures and ataxia, develop at a later stage and are produced by a characteristic deposition of lysosomal storage material in the brain. SCARB2 is the gene whose mutations are responsible for the disease. It codes for a lysosomal integral membrane protein that has pleiotropic molecular functions. Action myoclonus-renal failure syndrome is now considered a storage disease due to alterations in lysosome functions and, like any other conditions involving lysosomes, it is mainly characterized by degenerative lesions of the brain [68].

Nail-patella syndrome (OMIM\#161200) Nail-patella syndrome, also known as osteo-onychodysplasia, is an $\mathrm{AD}$ disorder classically producing dysplastic fingernails and hypoplastic or absent patella in association with renal defects that have been found in $40 \%$ of cases [69]. Glomerular changes involve both podocyte foot-process effacement [70] and thickening of the glomerular basement 
membrane as a result of the irregular deposition of fibrillar collagen type III [71]. The disease is caused by mutations of the $L M X 1 B$ gene that codes for a transcription factor active at a very early stage of podocyte development [70]. The $L m x l b$ gene knockout mice present a retarded maturation of podocytes that do not develop foot-processes nor express major slit-diaphragm genes, such as podocin and nephrin. Alterations of the glomerular basement membrane and of the endothelial fenestration suggest a direct role of $L M X 1 B$ at these sites [72].

\section{Galloway-Mowat syndrome (OMIM\#251300)}

The Galloway-Mowat syndrome is a rare condition originally described in 1968 in three sibs with the triad of congenital NS, microcephaly and hiatus hernia [73]. It is considered to be an AR disorder whose causative gene(s) are still unknown. Clinical features are generally represented by early onset NS with strict resistance to steroids and a poor prognosis [74]. Milder variants have also been reported, with the first renal symptom appearing after 10 years of age [75]. Renal pathology is also heterogeneous and varies from minimal changes to capillary proliferation, glomerulosclerosis and, in some cases, DMS [76].

\section{Mitochondrial cytopathies}

tRNA $A^{\text {Leu(UUR) }}$ Nephrotic syndrome may be part of a generalized defect induced by mutations in mitochondrial DNA (mtDNA). This condition preferentially affects the muscle and the nervous system but may also extend to the kidney. A typical example is the $\mathrm{A} 3243 \mathrm{G}$ transition in the $t R N A^{\operatorname{Leu}(U U R)}$ gene that is classically associated with MELAS syndrome (mitochondrial myopathy, encephalopathy, lactic acidosis, stroke episodes and occasional tubular defects) [77]. This mutation has also been found to be associated with FSGS in patients without any other sign of MELAS [78]. The clinical phenotype in children with an isolated renal defect is characterized by variable proteinuria, from mild to severe, with resistance to steroids and slow progression to end stage renal failure.

Co $Q_{10}$ deficiency: COQ2 and PDSS2 (OMIM\#607426) Congenital deficiency of coenzyme $\mathrm{Q}_{10}\left(\mathrm{CoQ}_{10}\right)$ includes a group of AR anomalies that are primarily characterized by neurological and muscular symptoms $[79,80]$ but may also present with isolated NS [81]. They are produced by mutations of genes coding for enzymes of the $\mathrm{CoQ}_{10}$ pathway, only a part of which have been identified. COQ2 is one of these genes. It codes for para-hydroxybenzoatepolyprenyl-transferase (EC 2.5.1.39), which catalyzes pre- nylation of para-hydroxybenzoate [82]. Mutations of $C O Q 2$ have been reported in association with isolated NS in two children and/or as part of a multi-organ defect producing progressive encephalopathy with muscular hypotonia and optic nerve atrophy in two other children. Severe NS with rapid progression to terminal renal failure is a predominant clinical feature. Renal histopathology was characterized by collapsing glomerulopathy and severe extracapillary proliferation in two cases, while FSGS was found in two siblings. Ultrastructural findings showed dysmorphic mitochondria with electron-lucent bodies in all cases and oncocyte-like aspects in a few. Biochemical analysis showed a decreased complex [II + III] activity in the renal cortex and skeletal muscle [81].

PDSS2 is the second gene implicated in $\mathrm{CoQ}_{10}$ deficiency syndrome. It codes for decaprenyl diphosphate synthase, the first enzyme of the $\mathrm{CoQ}_{10}$ biosynthetic pathway [83]. The first and unique case with compound heterozygous mutations of PDSS2 described to date presented [35] with severe Leigh syndrome characterized by seizures, hypotonia, cortical blindness and NS [83]. Biochemical analysis performed in muscles and fibroblasts demonstrated decreased complex [II + III] activity and a severe defect in decaprenyl diphosphate synthase.

Literature data indicate that children with congenital NS and encephalopathy should be screened for primary defect in $\mathrm{CoQ}_{10}$ biosynthesis. Cases with isolated renal defect, i.e. collapsing glomerulopathy or crescentic glomerulosclerosis, should also be screened. Molecular analysis of both COQ2 and PDSS2 is now available in several laboratories and should be performed in those patients with the above phenotypes. Therapy with coenzyme $\mathrm{Q}_{10}$ should be started very early since it may completely resolve NS [84] and actually represents the unique example of successful therapy for mitochondrial defects.

\section{Drug-responsive variants of NS}

Steroid-sensitive NS (SSNS) may occasionally occur in association with mutations of some of the genes mentioned above, but a good response to therapy is, in general, considered to be a rare event $[42,85,86]$. Two examples of inherited conditions responsive to steroids are the few cases with mild mutations of nephrin recently reported by Philippe and colleagues [42] and the unique girl carrying homozygous truncating PLCE1 mutations [35].

Familial aggregates and kindred with SSNS in geographical isolates have been described, suggesting a potential genetic origin. Very little data on molecular genetics of SSNS are available in the literature. A genome-wide scan for linkage has been recently conducted 
in 11 families with an $\mathrm{AR}$ trait, one of which was a consanguineous kindred from Germany. The first locus for SSNS was identified on chromosome $2 \mathrm{p} 12-13.2$ in an interval of $3.6 \mathrm{Mb}$ that contains approximately 60 known genes and 25 predicted genes [87]. The characterization of the first gene involved in NS responsive to steroids would represent a critical step in the definition of the underlying mechanism of non-inherited forms of the disease.

\section{Recurrence of disease after renal transplantation}

The underlying factors for post-transplant recurrence of proteinuria in FSGS remains an enigma. Patients with the sporadic variety of FSGS who have known homozygous or complex heterozygous traits present a low recurrence rate [88], and this appears to be a logical consequence of the fact that proteinuria is originally due to the inherited defect in the native organ while the grafted kidney is normal. This aspect has mostly been considered in patients with NPHS2 mutations. An original report by Bertelli and colleagues [89] described two patients with homozygous or compound heterozygous mutations of NPHS2 $(22 \%$ of those who received a renal graft), and in both cases the episode had a mild clinical impact with favorable outcome. Another two cases of recurrent FSGS have been recently described: one had the NPHS2 mutation [90] and the other had the WT1 mutation (IVS9+4C>T) and Frasier syndrome [91]. More recently, Sanna-Cherchi and colleagues [92] described a pedigree with AD FSGS of unknown origin in which the index case presented post-transplant recurrence of severe proteinuria and MCD. The identification of families with $\mathrm{AD}$ transmission and recurrence of disease has provided the chance to identify extra-renal factors involved in the pathogenesis of sporadic forms of FSGS. We now have the opportunity to consider post-transplant recurrence in a larger population and to compare the original data by Bertelli and colleagues [89] with other study cohorts [18, 19]. Collectively (including the study by Bertelli), data are available for 65 carriers of homozygous or compound heterozygous NPHS2 mutations, and the post-transplant recurrence of proteinuria was documented in five of these $(7.7 \%)$. It is worth reporting that one child with the homozygous p.L347X mutation described by Ruf and colleagues $[18,93]$ and another one with homozygous $\mathrm{p}$. R138X described by Weber and colleagues [19] received the kidney from their mother, who was an obligatory healthy heterozygous carrier. The first child had recurrence of proteinuria on day 7 from the graft and responded within 1 week to plasmapheresis. The second child presented nephrotic range proteinuria 2 years after the allograft. While the low number of patients with a single NPHS2 mutation does not allow any definite conclusion to be drawn, these results strongly suggest that the rate of recurrence in patients with NPHS2 homozygous or compound heterozygous mutations is low. Grafts from obligatory carriers of NPHS2 mutations, such as parents of affected individuals, should be avoided because of the higher risk of recurrence of FSGS.

Acknowledgments The authors would like to thank Dr. A. Capurro for language revision.

\section{Questions:}

(Answers appear following the reference list)

1. Which is the most frequent mode of inheritance of familial NS?

a) $\mathrm{AD}$

b) $\mathrm{AR}$

c) X-linked dominant

d) All

2. Genes involved in NS code most frequently for proteins of

a) glomerular basement membrane

b) podocytes

c) tubular epithelia

d) mesangial cells

3. TRCP6 mutations are associated with congenital NS

a) Yes, always

b) Often

c) Not yet

d) With Finnish nephropathy

4. PLCE1 usually causes DMS

a) In most cases

b) The association has never been reported

c) Is more frequently associated with FSGS

d) Is usually associated with hermaphroditism

5. NPHS1 truncating mutation $\left(\mathrm{Fin}_{\text {major }}\right)$ is prevalent in

a) Southern Europe

b) France

c) Finland

d) Only in Asia

6. Denys-Drash Syndrome is allelic with

a) Frasier syndrome

b) Leigh syndrome

c) NPHS1

d) $N P H S 2$

7. Which is the gene for Familial Steroid Sensitive NS?

a) $L A M B 2$

b) $A C T N 4$

c) $W T 1$

d) Never reported 


\section{References}

1. Braden GL, Mulhern JG, O'Shea MH, Nash SV, Ucci AA Jr, Germain MJ (2000) Changing incidence of glomerular diseases in adults. Am J Kidney Dis 35:878-883

2. McEnery PT, Strife CF (1982) Nephrotic syndrome in childhood. Management and treatment in patients with minimal change disease, mesangial proliferation, or focal glomerulosclerosis. Pediatr Clin North Am 29:875-894

3. Sharples PM, Poulton J, White RH (1985) Steroid responsive nephrotic syndrome is more common in Asians. Arch Dis Child 60:1014-1017

4. Korbet SM (1998) Primary focal segmental glomerulosclerosis. J Am Soc Nephrol 9:1333-1340

5. Border WA (1988) Distinguishing minimal-change disease from mesangial disorders. Kidney Int 34:419-434

6. Myllymaki J, Saha H, Mustonen J, Helin H, Pasternack A (2003) IgM nephropathy: clinical picture and long-term prognosis. Am J Kidney Dis 41:343-350

7. Lenkkeri U, Mannikko M, McCready P, Lamerdin J, Gribouval O, Niaudet PM, Antignac CK, Kashtan CE, Homberg C, Olsen A, Kestila M, Tryggvason K (1999) Structure of the gene for congenital nephrotic syndrome of the finnish type (NPHS1) and characterization of mutations. Am J Hum Genet 64:51-61

8. Boute N, Gribouval O, Roselli S, Benessy F, Lee H, Fuchshuber A, Dahan K, Gubler MC, Niaudet P, Antignac C (2000) NPHS2, encoding the glomerular protein podocin, is mutated in autosomal recessive steroid-resistant nephrotic syndrome. Nat Genet 24: 349-354

9. Kaplan JM, Kim SH, North KN, Rennke H, Correia LA, Tong HQ, Mathis BJ, Rodriguez-Perez JC, Allen PG, Beggs AH, Pollak MR (2000) Mutations in ACTN4, encoding alpha-actinin-4, cause familial focal segmental glomerulosclerosis. Nat Genet 24: 251-256

10. Churg J, Habib R, White RH (1970) Pathology of the nephrotic syndrome in children: a report for the International Study of Kidney Disease in Children. Lancet 760:1299-1302

11. Cohen AH, Border WA, Glassock RJ (1978) Nephrotic syndrome with glomerular mesangial IgM deposits. Lab Invest 38:610-619

12. D'Agati VD, Fogo AB, Bruijn JA, Jennette JC (2004) Pathologic classification of focal segmental glomerulosclerosis: a working proposal. Am J Kidney Dis 43:368-382

13. Tejani A, Nicastri AD, Sen D, Chen CK, Phadke K, Adamson O, Butt KM (1983) Long-term evaluation of children with nephrotic syndrome and focal segmental glomerular sclerosis. Nephron 35:225-231

14. Roselli S, Gribouval O, Boute N, Sich M, Benessy F, Attie T, Gubler MC, Antignac C (2002) Podocin localizes in the kidney to the slit diaphragm area. Am J Pathol 160:131-139

15. Schwarz K, Simons M, Reiser J, Saleem MA, Faul C, Kriz W, Shaw AS, Holzman LB, Mundel P (2001) Podocin, a raftassociated component of the glomerular slit diaphragm, interacts with CD2AP and nephrin. J Clin Invest 108:1621-1629

16. Caridi G, Berdeli A, Dagnino M, Di Duca M, Mir S, Cura A, Ravazzolo R, Ghiggeri GM (2004) Infantile steroid-resistant nephrotic syndrome associated with double homozygous mutations of podocin. Am J Kidney Dis 43:727-732

17. Caridi G, Bertelli R, Carrea A, Di Duca M, Catarsi P, Artero M, Carraro M, Zennaro C, Candiano G, Musante L, Seri M, Ginevri F, Perfumo F, Ghiggeri GM (2001) Prevalence, genetics, and clinical features of patients carrying podocin mutations in steroidresistant nonfamilial focal segmental glomerulosclerosis. J Am Soc Nephrol 12:2742-2746

18. Ruf RG, Lichtenberger A, Karle SM, Haas JP, Anacleto FE, Schultheiss M, Zalewski I, Imm A, Ruf EM, Mucha B, Bagga A,
Neuhaus T, Fuchshuber A, Bakkaloglu A, Hildebrandt F (2004) Patients with mutations in NPHS2 (podocin) do not respond to standard steroid treatment of nephrotic syndrome. J Am Soc Nephrol 15:722-732

19. Weber S, Gribouval O, Esquivel EL, Moriniere V, Tete MJ, Legendre C, Niaudet P, Antignac C (2004) NPHS2 mutation analysis shows genetic heterogeneity of steroid-resistant nephrotic syndrome and low post-transplant recurrence. Kidney Int 66:571-579

20. Berdeli A, Mir S, Yavascan O, Serdaroglu E, Bak M, Aksu N, Oner A, Anarat A, Donmez O, Yildiz N, Sever L, Tabel Y, Dusunsel R, Sonmez F, Cakar N (2007) NPHS2 (podicin) mutations in Turkish children with idiopathic nephrotic syndrome. Pediatr Nephrol 22:2031-2040

21. Hinkes B, Vlangos C, Heeringa S, Mucha B, Gbadegesin R, Liu J, Hasselbacher K, Ozaltin F, Hildebrandt F (2008) Specific podocin mutations correlate with age of onset in steroid-resistant nephrotic syndrome. J Am Soc Nephrol 19:365-371

22. Winn MP, Conlon PJ, Lynn KL, Howell DN, Slotterbeck BD, Smith AH, Graham FL, Bembe M, Quarles LD, Pericak-Vance MA, Vance JM (1999) Linkage of a gene causing familial focal segmental glomerulosclerosis to chromosome 11 and further evidence of genetic heterogeneity. Genomics 58:113-120

23. Winn MP, Conlon PJ, Lynn KL, Farrington MK, Creazzo T, Hawkins AF, Daskalakis N, Kwan SY, Ebersviller S, Burchette JL, Pericak-Vance MA, Howell DN, Vance JM, Rosenberg PB (2005) A mutation in the TRPC6 cation channel causes familial focal segmental glomerulosclerosis. Science 308:1801-1804

24. Reiser J, Polu KR, Moller CC, Kenlan P, Altintas MM, Wei C, Faul C, Herbert S, Villegas I, Avila-Casado C, McGee M, Sugimoto H, Brown D, Kalluri R, Mundel P, Smith PL, Clapham DE, Pollak MR (2005) TRPC6 is a glomerular slit diaphragmassociated channel required for normal renal function. Nat Genet 37:739-744

25. Winn MP (2008) 2007 Young Investigator Award: TRP'ing into a new era for glomerular disease. J Am Soc Nephrol 19:1071-1075

26. Weins A, Kenlan P, Herbert S, Le TC, Villegas I, Kaplan BS, Appel GB, Pollak MR (2005) Mutational and biological analysis of alpha-actinin-4 in focal segmental glomerulosclerosis. J Am Soc Nephrol 16:3694-3701

27. Choi HJ, Lee BH, Cho HY, Moon KC, Ha IS, Nagata M, Choi Y, Cheong HI (2008) Familial focal segmental glomerulosclerosis associated with an ACTN4 mutation and paternal germline mosaicism. Am J Kidney Dis 51:834-838

28. Shih NY, Li J, Karpitskii V, Nguyen A, Dustin ML, Kanagawa O, Miner JH, Shaw AS (1999) Congenital nephrotic syndrome in mice lacking CD2-associated protein. Science 286:312-315

29. Huber TB, Simons M, Hartleben B, Sernetz L, Schmidts M, Gundlach E, Saleem MA, Walz G, Benzing T (2003) Molecular basis of the functional podocin-nephrin complex: mutations in the NPHS2 gene disrupt nephrin targeting to lipid raft microdomains. Hum Mol Genet 12:3397-3405

30. Lowik MM, Groenen PJ, Pronk I, Lilien MR, Goldschmeding R, Dijkman HB, Levtchenko EN, Monnens LA, van den Heuvel LP (2007) Focal segmental glomerulosclerosis in a patient homozygous for a CD2AP mutation. Kidney Int 72:1198-1203

31. Kim JM, Wu H, Green G, Winkler CA, Kopp JB, Miner JH, Unanue ER, Shaw AS (2003) CD2-associated protein haploinsufficiency is linked to glomerular disease susceptibility. Science 300:1298-1300

32. Gigante M, Montemurno E, Roca L, Aucella F, Pontrelli P, Penza R, Caridi G, Ranieri E, Ghiggeri GM, Gesualdo L (2008) CD2AP mutations are associated with sporadic nephrotic syndrome and focal segmental glomerulosclerosis (FSGS). Nephrol Dial Transplant in press

33. Hinkes B, Wiggins RC, Gbadegesin R, Vlangos CN, Seelow D, Nurnberg G, Garg P, Verma R, Chaib H, Hoskins BE, Ashraf S, 
Becker C, Hennies HC, Goyal M, Wharram BL, Schachter AD, Mudumana S, Drummond I, Kerjaschki D, Waldherr R, Dietrich A, Ozaltin F, Bakkaloglu A, Cleper R, Basel-Vanagaite L, Pohl M, Griebel M, Tsygin AN, Soylu A, Muller D, Sorli CS, Bunney TD, Katan M, Liu J, Attanasio M, O'Toole JF, Hasselbacher K, Mucha B, Otto EA, Airik R, Kispert A, Kelley GG, Smrcka AV, Gudermann T, Holzman LB, Nurnberg P, Hildebrandt F (2006) Positional cloning uncovers mutations in PLCE1 responsible for a nephrotic syndrome variant that may be reversible. Nat Genet 38:1397-1405

34. Gbadegesin R, Hinkes BG, Hoskins BE, Vlangos CN, Heeringa SF, Liu J, Loirat C, Ozaltin F, Hashmi S, Ulmer F, Cleper R, Ettenger R, Antignac C, Wiggins RC, Zenker M, Hildebrandt F (2008) Mutations in PLCE1 are a major cause of isolated diffuse mesangial sclerosis (IDMS). Nephrol Dial Transplant 23:12911297

35. Hinkes BG (2008) NPHS3: new clues for understanding idiopathic nephrotic syndrome. Pediatr Nephrol 23:847-850

36. Kestila M, Lenkkeri U, Mannikko M, Lamerdin J, McCready P, Putaala H, Ruotsalainen V, Morita T, Nissinen M, Herva R, Kashtan CE, Peltonen L, Holmberg C, Olsen A, Tryggvason K (1998) Positionally cloned gene for a novel glomerular proteinnephrin - is mutated in congenital nephrotic syndrome. Mol Cell $1: 575-582$

37. Hinkes BG, Mucha B, Vlangos CN, Gbadegesin R, Liu J, Hasselbacher K, Hangan D, Ozaltin F, Zenker M, Hildebrandt F (2007) Nephrotic syndrome in the first year of life: two thirds of cases are caused by mutations in 4 genes (NPHS1, NPHS2, WT1, and $L A M B 2$ ). Pediatrics 119:e907-919

38. Beltcheva O, Martin P, Lenkkeri U, Tryggvason K (2001) Mutation spectrum in the nephrin gene (NPHS1) in congenital nephrotic syndrome. Hum Mutat 17:368-373

39. Heeringa SF, Vlangos CN, Chernin G, Hinkes B, Gbadegesin R, Liu J, Hoskins BE, Ozaltin F, Hildebrandt F (2008) Thirteen novel NPHS1 mutations in a large cohort of children with congenital nephrotic syndrome. Nephrol Dial Transplant 23:3527-3533

40. Tryggvason K, Patrakka J, Wartiovaara J (2006) Hereditary proteinuria syndromes and mechanisms of proteinuria. N Engl $\mathrm{J}$ Med 354:1387-1401

41. Liu L, Done SC, Khoshnoodi J, Bertorello A, Wartiovaara J, Berggren PO, Tryggvason K (2001) Defective nephrin trafficking caused by missense mutations in the NPHS1 gene: insight into the mechanisms of congenital nephrotic syndrome. Hum Mol Genet 10:2637-2644

42. Philippe A, Nevo F, Esquivel EL, Reklaityte D, Gribouval O, Tete MJ, Loirat C, Dantal J, Fischbach M, Pouteil-Noble C, Decramer $\mathrm{S}$, Hoehne M, Benzing T, Charbit M, Niaudet P, Antignac C (2008) Nephrin mutations can cause childhood-onset steroidresistant nephrotic syndrome. J Am Soc Nephrol 19:1871-1878

43. Haltia A, Solin ML, Holmberg C, Reivinen J, Miettinen A, Holthofer H (1998) Morphologic changes suggesting abnormal renal differentiation in congenital nephrotic syndrome. Pediatr Res 43:410-414

44. Liapis H (2008) Molecular pathology of nephrotic syndrome in childhood. A contemporary approach to diagnosis. Pediatr Dev Pathol 11:154-163

45. Patrakka J, Martin P, Salonen R, Kestila M, Ruotsalainen V, Mannikko M, Ryynanen M, Rapola J, Holmberg C, Tryggvason $\mathrm{K}$, Jalanko $\mathrm{H}$ (2002) Proteinuria and prenatal diagnosis of congenital nephrosis in fetal carriers of nephrin gene mutations. Lancet 359:1575-1577

46. Patrakka J, Kestila M, Wartiovaara J, Ruotsalainen V, Tissari P, Lenkkeri U, Mannikko M, Visapaa I, Holmberg C, Rapola J, Tryggvason K, Jalanko H (2000) Congenital nephrotic syndrome
(NPHS1): features resulting from different mutations in Finnish patients. Kidney Int 58:972-980

47. Kitamura A, Tsukaguchi H, Hiramoto R, Shono A, Doi T, Kagami S, Iijima K (2007) A familial childhood-onset relapsing nephrotic syndrome. Kidney Int 71:946-951

48. Koziell A, Grech V, Hussain S, Lee G, Lenkkeri U, Tryggvason K, Scambler P (2002) Genotype/phenotype correlations of NPHSI and NPHS2 mutations in nephrotic syndrome advocate a functional inter-relationship in glomerular filtration. Hum Mol Genet 11:379-388

49. Huber TB, Kottgen M, Schilling B, Walz G, Benzing T (2001) Interaction with podocin facilitates nephrin signaling. J Biol Chem 276:41543-41546

50. Gessler M, Konig A, Bruns GA (1992) The genomic organization and expression of the WT1 gene. Genomics 12:807-813

51. Hammes A, Guo JK, Lutsch G, Leheste JR, Landrock D, Ziegler U, Gubler MC, Schedl A (2001) Two splice variants of the Wilms' tumor 1 gene have distinct functions during sex determination and nephron formation. Cell 106:319-329

52. Baird PN, Santos A, Groves N, Jadresic L, Cowell JK (1992) Constitutional mutations in the WT1 gene in patients with DenysDrash syndrome. Hum Mol Genet 1:301-305

53. Barbaux S, Niaudet P, Gubler MC, Grunfeld JP, Jaubert F, Kuttenn F, Fekete CN, Souleyreau-Therville N, Thibaud E, Fellous M, McElreavey K (1997) Donor splice-site mutations in WT1 are responsible for Frasier syndrome. Nat Genet 17:467-470

54. Jeanpierre C, Denamur E, Henry I, Cabanis MO, Luce S, Cecille A, Elion J, Peuchmaur M, Loirat C, Niaudet P, Gubler MC, Junien C (1998) Identification of constitutional WT1 mutations, in patients with isolated diffuse mesangial sclerosis, and analysis of genotype/phenotype correlations by use of a computerized mutation database. Am J Hum Genet 62:824-833

55. Ruf RG, Schultheiss M, Lichtenberger A, Karle SM, Zalewski I, Mucha B, Everding AS, Neuhaus T, Patzer L, Plank C, Haas JP, Ozaltin F, Imm A, Fuchshuber A, Bakkaloglu A, Hildebrandt F (2004) Prevalence of WT1 mutations in a large cohort of patients with steroid-resistant and steroid-sensitive nephrotic syndrome. Kidney Int 66:564-570

56. Mucha B, Ozaltin F, Hinkes BG, Hasselbacher K, Ruf RG, Schultheiss M, Hangan D, Hoskins BE, Everding AS, Bogdanovic R, Seeman T, Hoppe B, Hildebrandt F (2006) Mutations in the Wilms' tumor 1 gene cause isolated steroid resistant nephrotic syndrome and occur in exons 8 and 9. Pediatr Res 59:325-331

57. Aucella F, Bisceglia L, De Bonis P, Gigante M, Caridi G, Barbano G, Mattioli G, Perfumo F, Gesualdo L, Ghiggeri GM (2006) WT1 mutations in nephrotic syndrome revisited. High prevalence in young girls, associations and renal phenotypes. Pediatr Nephrol 21:1393-1398

58. Pierson M, Cordier J, Hervouuet F, Rauber G (1963) An unusual congenital and familial congenital malformative combination involving the eye and kidney. J Genet Hum 12:184-213

59. Noakes PG, Miner JH, Gautam M, Cunningham JM, Sanes JR, Merlie JP (1995) The renal glomerulus of mice lacking s-laminin/ laminin beta 2: nephrosis despite molecular compensation by laminin beta 1 . Nat Genet 10:400-406

60. Wuhl E, Kogan J, Zurowska A, Matejas V, Vandevoorde RG, Aigner T, Wendler O, Lesniewska I, Bouvier R, Reis A, Weis J, Cochat P, Zenker M (2007) Neurodevelopmental deficits in Pierson (microcoria-congenital nephrosis) syndrome. Am J Med Genet 143A:311-319

61. Zenker M, Aigner T, Wendler O, Tralau T, Muntefering H, Fenski R, Pitz S, Schumacher V, Royer-Pokora B, Wuhl E, Cochat P, Bouvier R, Kraus C, Mark K, Madlon H, Dotsch J, Rascher W, Maruniak-Chudek I, Lennert T, Neumann LM, Reis A (2004) 
Human laminin beta2 deficiency causes congenital nephrosis with mesangial sclerosis and distinct eye abnormalities. Hum Mol Genet 13:2625-2632

62. Hasselbacher K, Wiggins RC, Matejas V, Hinkes BG, Mucha B, Hoskins BE, Ozaltin F, Nurnberg G, Becker C, Hangan D, Pohl M, Kuwertz-Broking E, Griebel M, Schumacher V, Royer-Pokora B, Bakkaloglu A, Nurnberg P, Zenker M, Hildebrandt F (2006) Recessive missense mutations in LAMB2 expand the clinical spectrum of LAMB2-associated disorders. Kidney Int 70:10081012

63. Kagan M, Cohen AH, Matejas V, Vlangos C, Zenker M (2008) A milder variant of Pierson syndrome. Pediatr Nephrol 23:323-327

64. Choi HJ, Lee BH, Kang JH, Jeong HJ, Moon KC, Ha IS, Yu YS, Matejas V, Zenker M, Choi Y, Cheong HI (2008) Variable phenotype of Pierson syndrome. Pediatr Nephrol 23:995-1000

65. Schimke RN, Horton WA, King CR (1971) Chondroitin-6sulphaturia, defective cellular immunity, and nephrotic syndrome. Lancet 2:1088-1089

66. Spranger J, Hinkel GK, Stoss H, Thoenes W, Wargowski D, Zepp F (1991) Schimke immuno-osseous dysplasia: a newly recognized multisystem disease. J Pediatr 119:64-72

67. Boerkoel CF, Takashima H, John J, Yan J, Stankiewicz P, Rosenbarker L, Andre JL, Bogdanovic R, Burguet A, Cockfield S, Cordeiro I, Frund S, Illies F, Joseph M, Kaitila I, Lama G, Loirat C, McLeod DR, Milford DV, Petty EM, Rodrigo F, Saraiva JM, Schmidt B, Smith GC, Spranger J, Stein A, Thiele H, Tizard J, Weksberg R, Lupski JR, Stockton DW (2002) Mutant chromatin remodeling protein SMARCAL1 causes Schimke immuno-osseous dysplasia. Nat Genet 30:215-220

68. Berkovic SF, Dibbens LM, Oshlack A, Silver JD, Katerelos M, Vears DF, Lullmann-Rauch R, Blanz J, Zhang KW, Stankovich J, Kalnins RM, Dowling JP, Andermann E, Andermann F, Faldini E, D'Hooge R, Vadlamudi L, Macdonell RA, Hodgson BL, Bayly MA, Savige J, Mulley JC, Smyth GK, Power DA, Saftig P, Bahlo M (2008) Array-based gene discovery with three unrelated subjects shows SCARB2/LIMP-2 deficiency causes myoclonus epilepsy and glomerulosclerosis. Am J Hum Genet 82:673-684

69. Sweeney E, Fryer A, Mountford R, Green A, McIntosh I (2003) Nail patella syndrome: a review of the phenotype aided by developmental biology. J Med Genet 40:153-162

70. Witzgall R (2008) How are podocytes affected in nail-patella syndrome. Pediatr Nephrol 23:1017-1020

71. Hoyer JR, Michael AF, Vernier RL (1972) Renal disease in nailpatella syndrome: clinical and morphologic studies. Kidney Int 2:231-238

72. Miner JH, Morello R, Andrews KL, Li C, Antignac C, Shaw AS, Lee B (2002) Transcriptional induction of slit diaphragm genes by $\mathrm{Lmx} 1 \mathrm{~b}$ is required in podocyte differentiation. J Clin Invest 109:1065-1072

73. Galloway WH, Mowat AP (1968) Congenital microcephaly with hiatus hernia and nephrotic syndrome in two sibs. J Med Genet 5:319-321

74. Kucharczuk K, de Giorgi AM, Golden J, Zacharowicz L, van den Heuvel LP, Kaplan BS (2000) Additional findings in GallowayMowat syndrome. Pediatr Nephrol 14:406-409

75. Koskimies O, Sariola H, Holmberg C, Rapola J (1991) Clinical quiz. Congenital nephrotic syndrome, microcephaly, brain malformations and diaphragmatic abnormality associated with histological features of diffuse mesangial sclerosis. Pediatr Nephrol $5: 433-435$

76. Cohen AH, Turner MC (1994) Kidney in Galloway-Mowat syndrome: clinical spectrum with description of pathology. Kidney Int 45:1407-1415
77. King MP, Koga Y, Davidson M, Schon EA (1992) Defects in mitochondrial protein synthesis and respiratory chain activity segregate with the tRNA(Leu(UUR)) mutation associated with mitochondrial myopathy, encephalopathy, lactic acidosis, and strokelike episodes. Mol Cell Biol 12:480-490

78. Yamagata K, Muro K, Usui J, Hagiwara M, Kai H, Arakawa Y, Shimizu Y, Tomida C, Hirayama K, Kobayashi M, Koyama A (2002) Mitochondrial DNA mutations in focal segmental glomerulosclerosis lesions. J Am Soc Nephrol 13:1816-1823

79. Mollet J, Giurgea I, Schlemmer D, Dallner G, Chretien D, Delahodde A, Bacq D, de Lonlay P, Munnich A, Rotig A (2007) Prenyldiphosphate synthase, subunit 1 (PDSS1) and OHbenzoate polyprenyltransferase (COQ2) mutations in ubiquinone deficiency and oxidative phosphorylation disorders. J Clin Invest 117:765-772

80. Salviati L, Sacconi S, Murer L, Zacchello G, Franceschini L, Laverda AM, Basso G, Quinzii C, Angelini C, Hirano M, Naini AB, Navas P, DiMauro S, Montini G (2005) Infantile encephalomyopathy and nephropathy with CoQ10 deficiency: a CoQ10responsive condition. Neurology 65:606-608

81. Diomedi-Camassei F, Di Giandomenico S, Santorelli FM, Caridi G, Piemonte F, Montini G, Ghiggeri GM, Murer L, Barisoni L, Pastore A, Muda AO, Valente ML, Bertini E, Emma F (2007) COQ2 nephropathy: a newly described inherited mitochondriopathy with primary renal involvement. J Am Soc Nephrol $18: 2773-2780$

82. Forsgren M, Attersand A, Lake S, Grunler J, Swiezewska E, Dallner G, Climent I (2004) Isolation and functional expression of human $C O Q 2$, a gene encoding a polyprenyl transferase involved in the synthesis of CoQ. Biochem J 382:519-526

83. Lopez LC, Schuelke M, Quinzii CM, Kanki T, Rodenburg RJ, Naini A, Dimauro S, Hirano M (2006) Leigh syndrome with nephropathy and CoQ10 deficiency due to decaprenyl diphosphate synthase subunit 2 (PDSS2) mutations. Am J Hum Genet 79:1125-1129

84. Montini G, Malaventura C, Salviati L (2008) Early coenzyme Q10 supplementation in primary coenzyme Q10 deficiency. N Engl J Med 358:2849-2850

85. Caridi G, Bertelli R, Di Duca M, Dagnino M, Emma F, Onetti Muda A, Scolari F, Miglietti N, Mazzucco G, Murer L, Carrea A, Massella L, Rizzoni G, Perfumo F, Ghiggeri GM (2003) Broadening the spectrum of diseases related to podocin mutations. J Am Soc Nephrol 14:1278-1286

86. Caridi G, Perfumo F, Ghiggeri GM (2005) NPHS2 (Podocin) mutations in nephrotic syndrome. Clinical spectrum and fine mechanisms. Pediatr Res 57:54R-61R

87. Ruf RG, Fuchshuber A, Karle SM, Lemainque A, Huck K, Wienker T, Otto E, Hildebrandt F (2003) Identification of the first gene locus (SSNS1) for steroid-sensitive nephrotic syndrome on chromosome 2p. J Am Soc Nephrol 14:1897-1900

88. Vincenti F, Ghiggeri GM (2005) New insights into the pathogenesis and the therapy of recurrent focal glomerulosclerosis. Am J Transplant 5:1179-1185

89. Bertelli R, Ginevri F, Caridi G, Dagnino M, Sandrini S, Di Duca M, Emma F, Sanna-Cherchi S, Scolari F, Neri TM, Murer L, Massella L, Basile G, Rizzoni G, Perfumo F, Ghiggeri GM (2003) Recurrence of focal segmental glomerulosclerosis after renal transplantation in patients with mutations of podocin. Am J Kidney Dis 41:1314-1321

90. Becker-Cohen R, Bruschi M, Rinat C, Feinstein S, Zennaro C, Ghiggeri GM, Frishberg Y (2007) Recurrent nephrotic syndrome in homozygous truncating NPHS2 mutation is not due to antipodocin antibodies. Am J Transplant 7:256-260 
91. Ghiggeri GM, Aucella F, Caridi G, Bisceglia L, Ghio L, Gigante M, Perfumo F, Carraro M, Gesualdo L (2006) Posttransplant recurrence of proteinuria in a case of focal segmental glomerulosclerosis associated with WT1 mutation. Am J Transplant 6:2208-2211

92. Sanna-Cherchi S, Somenzi D, Carnevali ML, Pilato FP, Carraro M, Ghiggeri GM, Allegri L (2006) Recurrent autosomal-dominant focal segmental glomerulosclerosis. Kidney Int 70:1664-1665

93. Billing H, Muller D, Ruf R, Lichtenberger A, Hildebrandt F, August C, Querfeld U, Haffner D (2004) NPHS2 mutation associated with recurrence of proteinuria after transplantation. Pediatr Nephrol 19:561-564

\section{Answers}

1. b) AR

2. b) Podocytes

3. c) Not yet

4. a) In most cases

5. c) Finland

6. a) Frasier syndrome

7. d) Never reported 